Walisongo Law Review (Walrev), Vol 2 No. 2 (2020)

DOI: 10.21580/Walrev/2020.2.2.6671

Copyright (C) 2020 Walisongo Law Review (Walrev)

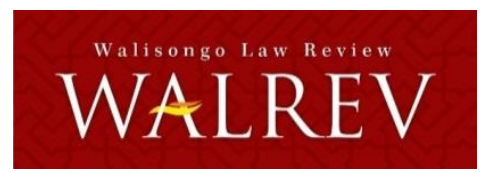

\title{
Settlement of Industrial Relations Disputes and Termination of Work Relations according to the Applicable Legislation
}

\author{
Agus Pramono \\ Afiliasi: Universitas Wisnuwardhana, Malang \\ Email: agus_pramono62@yahoo.co.id
}

\begin{abstract}
This article discusses the settlement of industrial relations disputes and termination of employment according to the applicable laws. Industrial relations disputes can be divided into two types: disputes over rights and disputes over interests. The relationship between workers and employers is a relationship that needs each other; workers need wages, employers benefit. However, in practice there are problems, so employers give Warning Letters I and II which are followed by Termination of Employment (PHK). The process of resolving this problem can be carried out through Bipartite, Mediation, or to the Industrial Relations Court. This paper is written with a normative juridical approach. The results show that the labor-employer problem is getting more complicated since the existence of the Omnibus Law on Job Creation, one of which contains the elimination of the city / district minimum wage (UMK) and replaced with the provincial minimum wage (UMP). The elimination of MSEs results in lower wages for workers. In fact, in the Manpower Act Number 13 of 2003 , no worker may receive a wage below the minimum wage, because the determination of wages is based on the calculation of Living Needs.
\end{abstract}


Artikel ini membahas mengenai penyelesaian perselisihan hubungan industrial dan pemutusan hubungan kerja menurut perundang-undangan yang berlaku. Perselisihan hubungan industrial menurut jenisnya dapat dibagi menjadi dua: perselisihan hak dan perselisihan kepentingan. Hubungan pekerja dan pengusaha merupakan hubungan yang saling membutuhkan; buruh memerlukan upah, pengusaha mendapatkan keuntungan. Namun, dalam prakteknya terjadi permasalahan, sehingga pengusaha memberikan Surat Peringatan I dan II yang diikuti dengan Pemutusan Hubugan Kerja (PHK). Proses penyelesaian persoalan ini dapat dilakukan melalui Bipartit, Mediasi, atau ke Pengadilan Hubungan Industrial. Tulisan ini ditulis dengan pendekatan yuridis normatif. Hasil penelitian menunjukkan bahwa permasalahan buruh-pengusaha semakin pelik seja hadirnya Undang-Undang Omnibus Law Cipta Lapangan Kerja yang salah satu isinya penghapusan upah minimum kota/kabupaten (UMK) dan diganti dengan upah minimum provinsi (UMP). Penghapusan UMK membuat upah pekerja lebih rendah. Padahal, dalam Undang-Undang Ketenagakerjaan Nomor 13 Tahun 2003 tak boleh ada pekerja yang mendapat upah di bawah upah minimum, karena penetapan upah didasarkan atas perhitungan Kebutuhan Layak Hidup.

Keywords: labor, entrepreneur, salary, termination of employment

\section{Introduction}

The occurrence of a dispute between the worker and the entrepreneur is something that is not easy to prevent, because a dispute can occur without a violation. For example, rationalization due to robotization; different interpretations of an applicable legal provision; the workers demand a 50\% increase in wages; or demand that health benefits be provided for their families (Simanjuntak 2011:151).

Labor disputes also occur as a result of default by the workers or by employers. The wishes of one party (generally workers) cannot always be fulfilled by the other party (employers), likewise the wishes of the entrepreneur are always violated or not always fulfilled by the 
workers or workers. The tendency to default by one party is a common thing. In addition to the conditions in society, daily life also affects the permanence of work relations.

Anxiety that is not handled as early as possible can lead to open disputes in the work relationship. Research in the field shows that the causes of this unrest include the low level of education of workers which causes obstacles in various matters, such as problems in communication. Education level also affects emotional level and tends to be high, difficult to accept other people's opinions and easily offended. In such circumstances, the sense of solidarity is strong. However, thanks to counseling and guidance in labor relations, workers' legal awareness has increased, so that violations of rights by workers have decreased in line with their increase in legal awareness. In addition, economic, social and cultural influences drive the demands of increasingly complex living needs.

The handling of unrest at the company level, whether it was initiated by a violation or that was not initiated by a violation by one of the parties, can be resolved through the workers' direct supervisor, who in this case is directly dealing with the worker. Likewise only with disputes that may occur. Procedures for handling worker unrest or complaints at the company level, or a collective labor agreement. This depends on whether the company in question already has a Company Regulation or a Collective Bargaining Agreement or not. How are industrial relations disputes resolved in the company according to the prevailing laws and regulations?

The objectives in this study are (1) to find out the factors that cause a repeat of the misuse of narcotics crime; (2) to find out the risks that can cause a repeat of the misuse of narcotics crime; and (3) actions taken in tackling repetition of misuse of narcotic crime.

\section{Discussion}

\section{Industrial Relations}

The term industrial relations comes from industrial relations, is a development of the term labor relations (labor relations or labor management relations) (Wijayanti 2014:56). The term labor relations 
gives a narrow impression as if it includes only the relationship between employers and workers. Basically, industrial relations covers a very broad aspect, namely socio-cultural, psychological, economic, political, legal and national defense and defense aspects so that industrial relations does not only include employers and workers, but involves the government and society in a broad sense (Kertonegoro 1999:14). Thus, the use of the term industrial relations is felt to be more appropriate than labor relations. The definition of industrial relations in the provisions of Article 1 number 16 Law no. 13 of 2003 states that industrial relations is a system of relations formed between actors in the process of producing goods and/or services consisting of elements from entrepreneurs, workers/laborers and government based on the values of Pancasila and the Constitution of the Republic of Indonesia 1945 (Pemerintah Republik Indonesia 2003:Article 1 (16); Sumanto 2014:133).

Industrial relations that prevail in Indonesia are Pancasila Industrial Relations, which are relations between actors in the production process of goods and services (workers, employers and the government) based on values which are the manifestation of the overall principles of Pancasila and The 1945 Constitution of the Republic of Indonesia which grows and develops on the personality and national culture of Indonesia (Pemerintah Republik Indonesia 1945).

Industrial Relations is a system of relationships that stretches out between actors in the process of producing goods and/or services consisting of elements from entrepreneurs, workers/laborers and the government based on Pancasila values and the 1945 Constitution of the Republic of Indonesia (Trijono 2020:90).

The characteristics of Pancasila Industrial Relations are:

a. acknowledge and believe that work is not only aimed at earning a living, but as a service to God, to fellow human beings, to society, the nation and the state;

b. consider workers not just a mere factor of production, but as individuals with all their dignity and dignity;

c. seeing that workers and employers do not have conflicting interests, but have the same interest, namely the progress of 
the company, because with an advanced company all parties will get welfare;

d. any disagreements between workers and employers must be resolved by way of deliberation to reach consensus which is carried out in a family manner; and

e. there is a balance between the rights and obligations of the two parties in the company, the balance is achieved not based on the balance of power, but on the basis of a sense of justice and appropriateness.

Industrial relations is a relationship between all parties related to or having an interest in the process of producing goods or services in a company, the interested parties in a company consist of: entrepreneurs or shareholders who are represented by management on a daily basis; workers and trade unions; supply companies; consumer society; user entrepreneurs, and the surrounding community. In addition to these stakeholders, industrial relations actors have developed by involving industrial relations consultants or lawyers, arbitrators, conciliators, mediators, and lecturers; as well as industrial relations court judges (Simanjuntak 2011:1).

The main functions of industrial relations are:

a. To maintain smooth or increase production

b. To maintain and create peace of work

c. To prevent and avoid strikes

d. To participate in creating and maintaining national stability.

Industrial relations will be harmonious if they are developed and implemented properly, so that they can help increase production, increase the possibility of employment opportunities, and help ensure an even distribution of the results of national development. In addition, industrial relations can assist the government in cooperating with employers 'and workers' organizations. So this relationship serves as a motivator to mobilize social participation and succeed in development so as to create peace of work and peace of business. 
Industrial relations will be said to be successful if there is an increase in productivity and welfare. Industrial relations are said to be unsuccessful when labor disputes arise, work relations are terminated, there are strikes or damage to property and other criminal acts (Wijayanti 2014:7). In order for industrial relations to take place properly, based on the provisions of Article 103 of Law No.13 of 2003, industrial relations facilities are determined (Rusli 2011:117), namely:

a. Trade unions/labor unions A trade/labor union is an organization formed from, by, and for workers/laborers, both within the company and outside the company, which is free, open, independent, democratic and responsible to fight for, defend and protect. rights and interests of workers/labor and improving the welfare of workers/labor and their families;

b. Employers 'organizations are like workers, employers also have the right and freedom to form or become members of employers' organizations or associations. The employers' association as an organization or association of representatives of the leadership of companies is a partner of trade unions and the government in handling labor issues and industrial relations. Employers' associations can be formed according to the industrial sector or type of business, starting from the local level to the district, provincial to central or national levels;

c. Bipartite cooperation institution, every company employing $5^{0}$ (fifty) workers/laborers or more is obliged to establish a bipartite cooperation institution. The bipartite cooperation institution functions as a communication and consultation forum regarding manpower matters in companies. The membership composition of a bipartite cooperation institution consists of an entrepreneur and a worker/laborer who is democratically appointed by the worker/laborer to represent the interests of the worker/laborer in the company concerned;

d. Tripartite cooperation institutions tripartite cooperation institutions are forums for communication, consultation and deliberation on manpower issues whose members consist of elements from employers' organizations, trade/labor unions 
and the government. Tripartite cooperation institutions consist of: national, provincial and district/city tripartite cooperation institutions and national, provincial and district/city sectoral tripartite cooperation institutions;

e. Company regulations Company regulations are those that are made in writing by an entrepreneur which contains working conditions and company rules. Entrepreneurs who employ at least 10 (ten) workers/laborers are obliged to make company regulations which come into force after being approved by the Minister or an appointed official;

f. Collective working agreement A collective working agreement is an agreement which is the result of negotiations between a trade / labor union or several trade/labor unions registered at the agency responsible for manpower affairs and an entrepreneur, or several entrepreneurs or a group of entrepreneurs that contains working conditions, the rights and obligations of both parties;

g. Manpower legislation and regulations basically cover provisions before work, during work, and after work. Regulations during work include provisions for working hours and rest, wages, protection, settlement of industrial relations disputes;

h. Industrial relations dispute settlement institutions Based on the provisions of Article 136 Law no. 13 of 2003 that the settlement of industrial relations disputes must be carried out by entrepreneurs and workers/laborers or trade/labor unions by deliberation to reach a consensus. In the event that a deliberative settlement for consensus cannot be reached, the employer and the worker or the labor union shall settle the industrial relations dispute through the industrial relations dispute settlement procedure which is regulated by law.

\section{Industrial Relations Disputes}

Industrial relations are basically a legal relationship between employers and workers, but sometimes the relationship experiences a dispute. Those disputes can happen to anyone who is in a legal relationship. Joni Emirzon who quotes in Lalu Husni's book gives an 
understanding of conflict/dispute/disagreement is a conflict or mismatch between the parties who will and are having a cooperative relationship (Husni 2014:2). Based on Article 1 number 1 of Law No.2 of 2004, the definition of industrial relations disputes is differences of opinion which result in conflicts between entrepreneurs or a combination of entrepreneurs and laborers or labor unions due to disputes over rights, disputes over interests, disputes over work relations, and disputes between unions. Llabor unions in a company. On the basis of this understanding, the elements of the conflict/dispute can be drawn (Husni 2014:3), namely:

a. There are parties (two or more people);

b. A different goal is that one party wants the other party to act/behave in accordance with what he wants;

c. The other party rejects the desire or the desire cannot be reconciled.

Basically, industrial relations disputes can be divided into 2 (two) parts (Widodo and Judiantoro 1992:12), namely Industrial disputes according to their nature: Collective disputes, namely disputes that occur between an entrepreneur/employer and a workers/labor union, due to the absence of a concurrent understanding of work relations, working conditions and/ or labor conditions; and Individual disputes, namely disputes between workers/laborers who are not members of a trade/labor union and an entrepreneur/employer. Industrial relations disputes by type: Disputes over rights, namely disputes arising between entrepreneurs/employers or employers' associations and workers/labor unions, because one of the parties to the work agreement or collective working agreement does not fulfill the contents of the work agreement or violates the legal provisions applicable to the relationship. work that they have agreed upon together; and Disputes over interests, namely conflicts between employers/employers or a combination of trade/labor unions in connection with the absence of a concurrent opinion on working conditions and/or labor conditions.

Meanwhile, in Article 2 of Law no. 2 of 2004 mentions several types of industrial relations disputes (Asyhadie and Kusuma 2018:119), namely: 
a. Disputes over Rights Based on Article 1 point 2 Law no. 2 of 2004 disputes over rights are disputes that arise because rights are not fulfilled, as a result of 31 differences in the implementation or interpretation of statutory provisions, work agreements, company regulations, or collective working agreements;

b. Disputes of Interest Based on Article 1 point 3 of Law No.2 of 2004, disputes of interest are disputes that arise in a work relationship because there is no conformity of opinion regarding the making, and/or changes in working conditions stipulated in work agreements, or company regulations, or agreements. work together;

c. Disputes over termination of employment based on Article 1 point 4 of Law no. 2 of 2004 disputes over termination of employment are disputes that arise because there is no conformity of opinion regarding the termination of employment relations carried out by one of the parties;

d. Disputes between trade unions/labor unions based on Article 1 point 5 of Law no. 2 of 2004 disputes between trade unions/labor unions are disputes between trade unions/labor unions and other trade unions/labor unions within one company only, because there is no concurrent understanding of membership, the exercise of rights and obligations of trade unions.

\section{Procedures for Settlement of Industrial Relations Disputes}

Prior to the enactment of Law No.2 of 2004, the settlement of industrial relations disputes was carried out based on Law Number 22 of 321957 concerning Settlement of Labor Disputes and Law Number 12 of 1964 concerning Termination of Employment in Private Companies (Pemerintah Republik Indonesia 2004). It turns out that the settlement of industrial relations disputes based on these two laws is no longer in accordance with the needs of society, because it can no longer accommodate developments that occur, especially regarding workers/labor rights (Lilik and Subroto 2011:61). Not only that, the dispute resolution process was also convoluted and took a long time to make it less effective. Industrial relations dispute settlement 
procedures as regulated in Law no. 2 of 2004 can be resolved through 2 (two) channels, namely settlement out of court (non-litigation) and settlement through court (litigation).

The settlement of industrial relations disputes outside the court can be carried out through bipartite negotiations and tripartite negotiations (mediation, conciliation, arbitration), while the settlement of industrial relations disputes through courts is carried out at the Industrial Relations Court.

Efforts must be made to resolve industrial relations disputes through deliberative bipartite negotiations to reach a consensus. This means that before the disputing parties invite a third party to resolve the issue between them, they must first begin the stage of negotiating the parties, which is commonly referred to as the bipartite approach.

Based on Article 1 point 10 of Law No.2 of 2004, bipartite negotiations are negotiations between workers/laborers or trade/labor unions and employers to resolve industrial relations disputes. Dispute settlement through bipartite is regulated in the provisions of Article 3 to Article 7 of Law no. 2 of 2004 (Jaedin 2020).

According to Article 3 of Law Number 2 of 2004 concerning the Settlement of Industrial Relations Disputes, in the first stage, the disputing parties are obliged to endeavor to resolve through peaceful means by deliberation to reach a consensus without involving a third party. According to the law, the best resolution is by the disputing parties by deliberation without the interference of other parties, so as to obtain results that are beneficial to both parties, in addition to saving costs and time (Hermawan 2018:87).

Settlement through bipartite negotiations must be completed no later than 30 (thirty) working days from the start date of the negotiations. If within 30 (thirty) days one of the parties refuses to negotiate or has conducted negotiations, but does not reach an agreement, then the bipartite negotiation is deemed a failure. Each bipartite negotiation minutes must be drawn up, signed by the parties. The negotiation minutes shall at least contain:

a. Full names and addresses of the parties;

b. The date and place of negotiations;

c. The subject matter or reason for the dispute; 
d. Opinions of the parties;

e. Conclusions or results of negotiations; and

f. Date and signatures of the parties conducting the negotiations (Article 6 paragraph (2) Law No.2 of 2004) (Asyhadie and Kusuma 2018:213).

If in the bipartite negotiations an agreement is reached, a collective agreement is made which is binding and becomes law and must be implemented by the parties. This Collective Agreement must be registered by the parties who entered into the agreement at the Industrial Relations Court at the District Court in the territory of the parties to enter into a Collective Agreement. In the event that the Collective Agreement is not implemented by one of the parties, the injured party may file a request for execution at the Industrial Relations Court at the District Court in the area in the Collective Agreement area to be registered to receive an order of execution.

Settlement of industrial relations disputes through mediation is carried out if no agreement is reached in bipartite negotiations. Efforts to settle industrial relations disputes through mediation are regulated in Article 8 through Article 16 of Law no. 2 of 2004. Based on Article 1 number 11 of Law no. 2 of 2004 is the settlement of disputes over rights, disputes over interests, disputes over termination of employment, and disputes between trade unions/labor unions within one company only through deliberation mediated by one or more neutral mediators.

The definition of a mediator is based on the provisions of Article 1 number 12 of Law no. 2 of 2004 are employees of government agencies responsible for manpower affairs who meet the requirements as mediators stipulated by the Minister to be in charge of mediation and have the obligation to provide written recommendations to disputing parties to resolve disputes over rights, disputes over interests, disputes over termination of relations work, and disputes between trade unions/labor unions in only one company. Settlement of disputes through mediation is carried out by a mediator who is in each agency office located in each district/city manpower office. Within no later than 7 (seven) working days after receiving the written request, the mediator must have conducted an 
investigation into the seat of the case and immediately hold a mediation session.

In the event that an agreement is reached for the settlement of industrial relations disputes through mediation, a Collective Agreement is drawn up which is signed by the parties and acknowledged by the mediator and registered at the Industrial Relations Court at the District Court in the area of the parties to enter into a Collective Agreement to obtain a proof of registration deed. Meanwhile, if the mediation does not reach an agreement, then:

a. the mediator issues a written recommendation;

b. written recommendation not later than 10 (ten) working days from the first mediation session to the parties;

c. the parties must have provided a written answer to the mediator which states that they agree or reject the written recommendation within no later than 10 (ten) working days after receiving the written recommendation;

d. parties that do not give their opinion are deemed to reject the written recommendation;

e. in the event that the parties agree to the written recommendation, then within 3 (three) working days from the approval of the written recommendation, the parties must have finished making a Collective Agreement to be registered at the Industrial Relations Court at the District Court in the jurisdiction of the parties holding Joint Agreement to get a proof of registration deed; and

$\mathrm{f}$. in the event that a written recommendation is rejected by one of the parties or the parties, then the parties or one of the parties can continue the dispute settlement to the Industrial Relations Court at the local District Court.

The mediator completes his / her duties within no later than 30 (thirty) working days from receiving the delegation of dispute resolution.

Settlement of industrial relations disputes through conciliation is regulated in Article 17 to Article 28 of Law No.2 of 2004. Based on Article 1 number 13 of Law no. 2 of 2004, Industrial Relations 
Conciliation, hereinafter referred to as conciliation, is the settlement of interests, disputes over termination of employment, or disputes between trade unions/labor unions within one company only through deliberations mediated by one or more neutral conciliators. What is meant by a conciliator based on Article 1 number 14 of Law No.2 of 2004 is a person or more who meets the requirements as a conciliator determined by the Minister, who is in charge of conciliation and is obliged to provide written recommendations to the parties in dispute to resolve disputes over interests. Disputes over termination of employment or disputes between trade unions/labor unions in only one company.

The settlement by the conciliator is carried out after the parties submit a written request for settlement to the conciliator appointed and agreed by the parties. Within no later than 7 (seven) working days, the conciliator must have conducted research on the sit-down of the case and by no later than the eighth working day the first conciliation session must have been held.

In the event that a settlement agreement is reached through conciliation, a Collective Agreement is drawn up which is signed by the parties known to the conciliator and is registered at the Industrial Relations Court at the Denpasar District Court in the area of the parties to enter into a Collective Agreement. Meanwhile, if no settlement agreement is reached through conciliation, then:

a. the conciliator issues written recommendations;

b. the written recommendation within 10 (ten) working days from the first conciliation session must have been submitted to the parties;

c. the parties must have provided a written answer to the conciliator which states that they agree or reject the written recommendation within no later than 10 (ten) working days after receiving the written recommendation;

d. parties that do not give their opinion are deemed to reject the written recommendation;

e. in the event that the parties agree to the written recommendation, then within 3 (three) working days from the approval of the written recommendation, the conciliator must 
have finished assisting the parties to make a Collective Agreement to be registered at the Industrial Relations Court at the District Court in the jurisdiction of the parties. the party entered into a Joint Agreement to get a proof of registration deed; and

f. in the event that a written recommendation is rejected by one of the parties or the parties, then the party or one of the parties can continue the dispute settlement to the Industrial Relations Court at the local District Court. The conciliator completes its duties within 30 (thirty) working days from receiving the dispute settlement request.

The institution authorized to referee disputes over interests and disputes between unions is the arbitrator. These arbitrators can be selected by the disputing parties from the list of arbitrators established by the minister (Wijayanti 2014:119). Settlement through arbitration is regulated in Article 29 to Article 54 of Law No.2 of 2004. Based on Article 1 number 15 of Law No.2 of 2004, arbitration is the settlement of disputes over interests, and disputes between trade unions/labor unions in only one company, in outside the Industrial Relations Court through a written agreement from the disputing parties to submit dispute resolution to the arbitrator whose decision is binding on the parties and is final. Whereas what is meant by arbitrators based on Article 1 number 16 Law No.2 of 2004 is a person or more who is selected by the parties in dispute from the list of arbitrators established by the Minister to give decisions regarding disputes over interests and disputes between trade unions/labor unions a company whose settlement is submitted through arbitration, the decision is binding on the parties and is final.

The arbitrator's industrial relations dispute settlement begins with an attempt to reconcile the two disputing parties. If peace is reached, the arbiter or arbiter council is obliged to make a Settlement Deed signed by the disputing parties and the arbitrator or arbiter council. However, if the reconciliation effort fails, the arbitrator or panel of arbitrators will continue the arbitration session. An arbitration award has legal force that binds the disputing parties and is a final and permanent award. The arbitration award is registered at the Industrial Relations Court at the District Court in the arbiter's 
territory to determine the decision. Industrial relations disputes that are 40 or have been resolved through arbitration cannot be submitted to the Industrial Relations Court.

The Special Industrial Relations Court is a special court within the general court (Article 55). The procedural law in effect is a civil procedural law that applies to courts within the domain of general courts unless specifically regulated (Article 57) (Suryandoro, Widodo, and Uwiyono 2018:156).

If the bipartite or tripartite settlement also fails, the industrial relations dispute settlement can be pursued through the Industrial Relations Court as the body or vehicle that provides justice, while the judiciary shows the process of providing justice in order to enforce the law (Basah 1989:23). The Industrial Relations Court is a form of industrial relations dispute settlement taken as a final alternative and legally this is not an obligation of the disputing parties, but a right (Khakim 2014:154-155).

Based on Article 1 anngka 17 Law no. 2 of 2004, the Industrial Relations Court is a special court established within the district court which has the authority to examine, hear and give decisions on industrial relations disputes. For the first time an Industrial Relations Court is established in every Regency/City District Court located in each Provincial Capital whose jurisdiction covers the province concerned.

Judges are career judges at the District Court who are appointed to examine industrial relations dispute cases and are dismissed by the Chief Justice of the Supreme Court. Ad-Hoc Judges are Ad-Hoc Judges at the Industrial Relations Court and Ad-Hoc Judges at the Supreme Court whose appointments are based on proposals from trade unions/labor unions and employers' organizations. Ad-Hoc judges are not career judges, and therefore the term of office is limited to a period of 5 (five) years and can be reappointed for 1 (one) term of office. Cassation Judge Is the Supreme Court Judge and AdHoc Judge at the Supreme Court who has the authority to examine, hear and give decisions on industrial relations disputes.

The procedural law that applies to the Industrial Relations Court is the Civil Procedure Law that applies to Courts within the General 
Courts, except as specifically regulated in this law. In the proceedings at the Industrial Relations Court, the parties in a case are not charged a fee, including the cost of execution, whose claim value is below $\mathrm{Rp}$. 150,000,000.00 (one hundred and fifty million rupiah) Based on the provisions of Law no. 2 of 2004 the mechanism for resolving industrial relations disputes through the Industrial Relations Court:

a. Submission of Lawsuit Lawsuit;

b. Examination by Ordinary Procedure;

c. Quick Events Checkup;

d. Decision Making.

Industrial relations dispute cases are different from civil and criminal cases, in industrial relations dispute cases there is no appeal. This is intended so that industrial relations dispute cases will quickly gain permanent or final legal force. However, if the parties in the case are not satisfied with the judge's decision at the first level, the parties can make an appeal to the Supreme Court.

Cases that can be filed for cassation to the Supreme Court are related to disputes over rights and termination of employment, while for disputes over interests and disputes between trade unions / labor unions in a company, if they have been decided at the first level court, namely the Industrial Relations Court at the District Court, the decision is in the nature final and fixed (Lilik and Subroto 2011).

The Industrial Relations Dispute Settlement Law mandates that cassation decisions to resolve rights disputes or termination disputes are no later than 30 working days from the date of receipt of the application. The cassation decision can be in the form of rejecting, canceling or granting the cassation (AB. and Florencianoy 2008:42).

At the cassation level, the Supreme Court has the authority to overturn a decision due to, among others:

a. The court is not authorized or exceeds the limits of its authority;

b. The rights tribunal is either implementing or violating applicable laws; and

c. The panel of judges neglected to fulfill the requirements required by law which threatened the negligence with the 
cancellation of the act concerned (AB. and Florencianoy 2008:43-47).

The refusal of cassation is more related to Judex Factie, such as the judge does not apply the law wrongly or the appeal submitted is not the authority of the cassation judge or it may be because the reason for the appeal for cassation is not in accordance with the subject matter of the case. On the other hand, the Supreme Court can grant the cassation because the court has wrongly applied or violated the applicable law or failed to fulfill the requirements required by the law which threatens negligence by invalidating the decision.

Meanwhile, the review is an extraordinary legal effort, which is intended so that the decisions of the courts, including the Industrial Relations Court or the Supreme Court decisions that have legal force continue to return to not having permanent legal force. Submission of judicial review can be made if certain circumstances are determined by law, such as new evidence (novum) and/or judges' errors in applying the law.

\section{Terms of Termination of Employment}

The relationship between workers/laborers and employers does not always run well. Humans as social beings in their interactions, of course, there are similarities and differences in interests and views, so that during the implementation of the work relationship between workers/laborers and employers there is a possibility of a dispute that leads to termination of employment (PHK). Then Husni in his book states that "Termination of employment is the termination of employment relations between employers and workers for various reasons." (Husni 2014:159; Lathifah, Ernawati, and Yuningrum 2016)

According to Article 1 number 25 Law no. 13 of 2003, what is meant by termination of employment relations is the termination of the employment relationship due to certain matters which resulted in the termination of rights and obligations between workers/laborers and entrepreneurs. Based on Article 150 of Law no. 13 of 2003, termination of employment includes termination of employment that occurs in a legal entity or not, owned by an individual, owned by an association or legal entity, both private and state owned, as well as 
social enterprises and other businesses have management, and employ other people by paying wages or other forms of compensation.

Layoffs are an unexpected event. Especially for workers, because termination of employment will have a psychological and financial impact on workers and their families (Djumaldji and Wiwoho 1985:88), because:

a. with the termination of employment relations, workers have lost their livelihoods;

b. to find a new job to replace it, it costs a lot; and

c. losing the cost of living for himself and his family before getting a new job to replace him (Asikin 2010:174).

Employers are prohibited from laying off employees if it is based on reasons based on Article 153 paragraph (1) of Law no. 13 of 2003, namely:

a. Workers/laborers are unable to come to work due to illness, according to a doctor's statement, as long as the period does not exceed 12 (twelve) months continuously;

b. Workers/laborers are unable to carry out their work because they fulfill obligations towards the state in accordance with the provisions of the applicable laws;

c. Workers/laborers carry out worship that is ordered by their religion;

d. Married workers/laborers;

e. Female workers/laborers who are pregnant, give birth, abort or breastfeed their babies;

f. Workers/laborers are related by blood and/or marital ties with other workers/laborers in one company, unless it has been regulated in a work agreement, company regulations, or collective working agreement;

g. Workers/laborers establish, become members and or administrators of a trade/labor union, workers/laborers carry out trade union/labor union activities outside of working hours, or during working hours as agreed by the entrepreneur, or based on the provisions stipulated in the work agreement, regulations. company, or collective working agreement; 
h. Workers/laborers who report the entrepreneur to the authorities regarding the entrepreneur's act of committing a criminal act;

i. Due to differences in understanding, religion, political ideology, ethnicity, skin color, class, gender, physical condition, or marital status; and

j. Workers/laborers are permanently disabled, sick due to work accidents, or sick due to work relations which according to a doctor's certificate, the period of healing has not been confirmed (Rusli 2011:150).

Termination of employment for the reasons mentioned above is null and void and the employer is obliged to re-employ the worker concerned. The reasons that are allowed as the basis for termination of employment are: because the worker made a serious mistake; because the worker is detained by the authorities; because it has been given a third warning letter; due to changes in company status; because the company closed; because the company is bankrupt; because the worker died; due to retirement; because of absenteeism; because the entrepreneur has committed an inappropriate act; out of self-will; and due to prolonged illness or disability due to work accidents.

In Law no. 13 of 2003 stipulates that if all efforts have been made, but dismissal is unavoidable, employers are obliged to pay severance pay and/or service pay and compensation for rights that should have been received (Indarti, Masyithoh, and Nurhayati 2020).

\section{Types of Termination of Employment}

Basically, layoffs can be divided into 4 (four) types, namely layoffs for the sake of law, layoffs by workers/laborers, layoffs by employers, and layoffs due to court decisions.

a. Termination of Employment by Law

Termination of employment by law means that the employment relationship must be terminated by itself and addressed to workers or laborers, employers do not need to obtain a dismissal determination from the authorized institution. Termination of employment by law 
can occur in cases as regulated in Law no. 13 of 2003 Article 154, namely:

1. a worker/laborer is still in a probationary period, if it has been agreed in writing beforehand;

2. The worker/laborer submits a resignation request, in writing of his own accord without any indication of pressure/intimidation from the entrepreneur, the termination of the working relationship in accordance with the work agreement for a specified time for the first time;

3. The worker/laborer reaches the retirement age in accordance with the provisions in the work agreement, company regulations, collective work agreement or statutory regulations; or

4. The worker/laborer dies.

b. Termination of Employment by Workers/Laborers

Termination of Employment by the worker/laborer, that is, layoff by the worker occurs because of the wishes of the worker. Based on Law no. 13 of 2003 layoffs by workers/labor can be carried out as follows:

1. The worker/laborer resigns (Article 162).

2. Workers/laborers are not willing to continue working relations due to changes in status, mergers, consolidations and changes in company ownership (Article 163 paragraph (1)).

3. application of workers/labor to industrial relations dispute settlement institutions (Article 169 paragraph (2)).

4. application for workers/labor due to prolonged illness, experiencing permanent disability due to work accidents (Article 172).

Based on Article 169 paragraph (1) of Law no. 13 of 2003, workers/laborers can apply for termination of employment to industrial relations dispute settlement institutions in the event that the entrepreneur makes the following mistakes:

1. to abuse, humiliate or threaten workers/laborers.

2. persuade and/or order workers/laborers to commit acts that are contrary to statutory regulations. 
3. Failure to pay the stipulated wages on time for 3 (three) consecutive months.

4. does not perform the obligations that have been promised to the worker/laborer.

5. To order workers/laborers to carry out work outside what was agreed upon.

6. gives a job that endangers the life, safety, health and difficulties of the worker/laborer, while the job is not included in the work agreement.

c. Termination of Employment by Employer/Entrepreneur

Based on Law no. 13 of 2003, the entrepreneur can terminate the worker/laborer if the worker / laborer does the following:

1. a worker/laborer commits a serious mistake (Article 158 paragraph (1));

2. Workers/laborers are detained by the authorities (Article 160 paragraph (3));

3. The worker/laborer commits disciplinary action, by violating the provisions stipulated in the work agreement, company regulations or collective working agreement (Article 161 paragraph (1));

4. change of status, merger and consolidation of companies (Article 163);

5. the company is closed because it has suffered a loss, has been audited late and is declared to have suffered a loss by the public accountant (Article 164 paragraph (2));

6. The worker/laborer dies (Article 166);

7. The worker/laborer reaches the age of retirement in accordance with the provisions in the work agreement, company regulations, collective labor agreement or legislation (Article 167 paragraph (1));

8. Qualified absent workers/laborers resign (Article 168 paragraph (1));

9. The worker/laborer has complained and reported that the entrepreneur has made a mistake but it is not proven (Article 169 paragraph (3)). 
Termination of Employment due to Court Decision The way in which the last dismissal occurs is because of a court decision. This fourth method is actually the result of a dispute between the worker and the employer which continues through the court process. The case can come from workers or can be from the employer (Wijayanti 2014:167). Termination by court, that is, dismissal by a court decision occurs for certain urgent and important reasons, for example a transfer of ownership, a transfer of assets or bankruptcy.

\section{The rights of laid-off workers}

If layoffs cannot be avoided, then according to the reasons underlying the layoffs, the employer is obliged to pay severance pay and/or work period award money which is adjusted to the length of service and compensation for rights.

The provisions for severance pay are based on Article 156 paragraph (2) of Law 13 of 2003, namely:

a. Working period of less than 1 year, 1 month of wages:

b. Working period of 1 year or more but less than 2 years, 2 months of wages;

c. Work period of 2 years or more but less than 3 years, 3 months of wages;

d. Working period of 3 years or more but less than 4 years, 4 months of wages;

e. Working period of 4 years or more but less than 5 years, 5 months of wages;

f. Working period of 5 years or more but less than 6 years, 6 months of wages;

g. Work period of 6 years or more but less than 7 years, 7 months of wages;

h. Work period of 7 years or more but less than 8 years, 8 months of wages;

i. Work period of 8 years or more, 9 months of wages.

Provisions for working period awards are based on Article 156 paragraph (3) of Law No. 13 of 2003, namely:

a. Working period of 3 years or more but less than 6 years, 2 months of wages; 
b. Work period of 6 years or more but less than 9 years, 3 months of wages;

c. Work period of 9 years or more but less than 12 years, 4 months of wages;

d. Work period of 12 years or more but less than 15 years, 5 months of wages;

e. Work period of 15 years or more but less than 18 years, 6 months of wages;

f. Work period of 18 years or more but less than 21 years, 7 months of wages;

g. Work period of 21 years or more but less than 24 years, 8 months of wages;

h. Work period of 24 years or more, 10 months of wages.

Rights compensation which should have been received under Article 156 paragraph (4) of Law No. 13 of 2003 includes:

a. Annual leave that has not been taken and has not failed;

b. Return costs or fees for workers/laborers and their families to the place where the workers/laborers are accepted to work;

c. Housing compensation as well as medication and care is set at $15 \%$ of the eligible severance pay and / or service pay;

d. Other matters stipulated in work agreements, company regulations or collective labor agreements.

\section{Conclusion}

Settlement of Industrial relations disputes and layoffs according to applicable laws in accordance with Law Number 13 of 2003 concerning Manpower and Law Number 2 of 2004 concerning PPHI. Industrial relations disputes according to their types can be divided into 2, namely disputes over rights and disputes over interests. Basically, the relationship between workers/labor and entrepreneurs is a mutual relationship, namely workers/laborers need a salary or wages while the entrepreneur also wants to get some benefit. However, in practice the relationship between the two parties is sometimes not harmonious because of problems in the work relationship, so the employer gives a warning letter and if I and II are 
not heeded, it is followed by Termination of Employment (PHK) by the employer against the worker.

The settlement process can be through Bipartite, but also cannot be completed by Bipartite, so it can be submitted to the Manpower Office through Mediation or conciliation, in the case of settlement at the level of completion of the Manpower Office, the parties are given the opportunity to choose to be completed by a mediator or conciliator. The settlement process at the Mediation level by the Mediator, the Mediator summons both parties for questioning and submitting evidence. Furthermore, the Mediator issues a decision in the form of recommendations. If the recommendation cannot be finished, the case is submitted to the Industrial Relations Court. Furthermore, the decision from the Industrial Relations Court, if one of the parties is not satisfied, then an appeal can be submitted to the Supreme Court.

On October 5, 2020, the Omnibus Law on Employment Creation was passed. One of the points rejected by the labor union was the elimination of the city/district minimum wage (UMK) and replaced with the provincial minimum wage (UMP). The elimination is considered to have lowered workers' wages. In fact, in the Manpower Act Number 13 of 2003, it is stated that no worker may receive wages below the minimum wage. Both the UMP and UMK are determined by the governor by taking into account the recommendations of the provincial wage councils and regents/mayors. The determination of the UMK and UMP is based on the calculation of the Living Needs. $[\mathrm{w}]$

\section{Reference}

AB., Nemen and Gloria Florencianoy. 2008. Panduan Praktis Menghitung Pesangon. Jakarta: Forum Sahabat.

Asikin, Zaenal. 2010. Dasar-Dasar Hukum Perburuhan. Jakarta: Raja Grafindo Persada.

Asyhadie, Zaeni and Rahmawati Kusuma. 2018. Hukum Ketenagakerjaan Dalam Teori Dan Praktik Di Indonesia. Jakarta: Prenada Media. 
Basah, Sjachran. 1989. Eksistensi Dan Tolak Ukur Badan Peradilan Administrasi Di Indonesia. Bandung: Alumni.

Djumaldji, F. X. and Soerjono Wiwoho. 1985. Perjanjian Perburuhan Dan Hubungan Perburuhan Pancasila. Jakarta: Bina Aksara.

Hermawan, Ari. 2018. Penyelesaian Sengketa Hubungan Industrial. Yogyakarta: UII Pres.

Husni, Lalu. 2014. Pengantar Hukum Ketenagakerjaan Indonesia. Jakarta: Rajawali Pers.

Indarti, Retno, Novita Dewi Masyithoh, and Tri Nurhayati. 2020. "Legal Protection for Disability Workers in Semarang: Case Study at PT. Samwon Busana Indonesia." Walisongo Law Review (Walrev) 2(1).

Jaedin, Jaedin. 2020. "Annual Leave Entitlement of Labor (A Comparison between Egypt Law with Indonesia)." Walisongo Law Review (Walrev) 2(1).

Kertonegoro, Sentanoe. 1999. Hubungan Industrial, Hubungan Antara Pengusaha Dan Pekerja (Bipartid) Dan Pemerintah (Tripartid). Jakarta: YTKI.

Khakim, Abdul. 2014. Dasar-Dasar Hukum Ketenagakerjaan Indonesia. Bandung: Citra Aditya Bakti.

Lathifah, Anthin, Briliyan Ernawati, and Heny Yuningrum. 2016. "Pemberdayaan Ekonomi Pekerjaan Rumah Tangga Melaui Pelatihan Kerajinan Payet Di Kelurahan Sumurbroto Kecamatan Banyumanik Semarang." Dimas: Jurnal Pemikiran Agama Untuk Pemberdayaan 15(1):39-56.

Lilik, Mulyadi and Agus Subroto. 2011. Penyelesaian Perkara Pengadilan Hubungan Industrial Dalam Teori Dan Praktek. Bandung: Alumni.

Pemerintah Republik Indonesia. 1945. Undang-Undang Dasar 1945.

Pemerintah Republik Indonesia. 2003. "Undang-Undang Republik Indonesia No. 13 Tahun 2003 Tentang Ketenagakerjaan."

Pemerintah Republik Indonesia. 2004. "Undang-Undang Republik Indonesia Nomor 2 Tahun 2004 Tentang Penyelesaian Perselisihan Hubungan Industrial.” 
Rusli, Hardijan. 2011. Hukum Ketenagakerjaan. Bogor: Ghalia Indonesia.

Simanjuntak, Payaman J. 2011. Manajemen Hubungan Industrial. Jakarta: Lembaga Penerbit, Fakultas Ekonomi, Universitas Indonesia.

Sumanto. 2014. Hubungan Industrial, Cet. I. Yogyakarta: Center Of Academic Publishing Service.

Suryandoro, Widodo, and Aloysius Uwiyono. 2018. Asas-Asas Hukum Perburuhan. Depok: Rajawali Pers.

Trijono, Rachmat. 2020. Omnibus Law Cipta Lapangan Kerja. Jakarta: Papas Sinar Sinanti.

Widodo, Hartono and Judiantoro. 1992. Segi Hukum Penyelesaian Perselisihan Perburuhan. Jakarta: Rajawali Pers.

Wijayanti, Asri. 2014. Hukum Ketenagakerjaan Pasca Reformasi, Cet. 4. Jakarta: Sinar Grafika. 